\title{
Osoby bezdomne a ich poczucie godności osobistej
}

Artykuł porusza problematykę poczucia godności osób bezdomnych. Zaprezentowano w nim wyniki badań zastanych na temat godności i godnego traktowania niemających dachu nad głową oraz wyniki badań własnych, które odnoszą się do specyficznego, dotychczas pomijanego w krajowej literaturze z zakresu pedagogiki, psychologii czy socjologii, tematu poczucia godności osobistej bezdomnych. Otrzymane wyniki ujawniły, że badane bezdomne kobiety cechuje niższe poczucie godności osobistej w porównaniu do bezdomnych mężczyzn biorących udział w badaniach ( $\mathrm{p}<0,001)$. Ponadto, uwzględniając miejsce pobytu bezdomnych, tzn. „uliczni” vs „schroniskowi”, okazało się, że bezdomni "uliczni” odczuwają wyższe poczucie godności osobistej aniżeli bezdomni na co dzień mieszkający w schroniskach i innych placówkach świadczących całodobową pomoc i wsparcie dla tej grupy osób $(\mathrm{p}<0,05)$. Czas pozostawania w bezdomności wykazał również istotną różnicę pomiędzy osobami bezdomnymi z najkrótszym i najdłuższym stażem $(\mathrm{p}<0,01)$. Otrzymanych wyników badań nie można uogólniać na całą populację osób bezdomnych w Polsce, mogą być jednak podstawą do prowadzenia badań na większej populacji bezdomnych.

Słowa kluczowe: bezdomność, bezdomny, godność, poczucie godności osobistej

\section{Homeless Persons and Their Sense of Self-Dignity}

The article discusses the issue of the sense of self-dignity of homeless people. It presents the results of researches on the dignity and dignified treatment those who have no roof over their head and the results of authors' own research, which referes to the specific sense of self-dignity of the homeless - the problem which so far is omitted in the national literature on pedagogy, psychology or sociology. Results of the research showed that lower level of the self-dignity was more characterizing homeless women comparing to homeless men $(p<0.001)$. Moreover taking the place of stay of the homeless under consderation - living on the "street" vs at a "hostel" - it turned out that the "street" homeless usually have higher sense of self -dignity than homeless living in hostels and other institutions providing 24-hour assistance for this group of people $(\mathrm{p}<0.05)$. The time of remaining in the homelessness also demonstrated the important difference between homeless persons with the shortest and longest period of being without the roof over their heads $(p<0.01)$. It is not possible to generalize received data to the whole population of the homeless in Poland, however it can be a base for the next examination on the larger population of the homeless.

Keywords: homelessness, homeless, dignity, sense of self-dignity 


\section{Wprowadzenie}

Bezdomność jest problemem społecznym, który w Polsce przez wiele lat nie był poddawany analizom teoretycznym ani empirycznym. Zaczęto go badać i opisywać po transformacji ustrojowej. Stało się tak z dwóch powodów. Po pierwsze, zmiana systemu stworzyła „przestrzeń” dla przedstawicieli różnych dyscyplin naukowych (m.in. pedagogiki - głównie społecznej i resocjalizacyjnej, socjologii, psychologii, polityki społecznej czy psychiatrii) do nagłośnienia kwestii, która choć faktycznie istniała, to ze względu na polityczną ideologię nie mogła być nagłaśniana [por. Tarkowska 2000: 9]. Po drugie, na skutek likwidacji Państwowych Gospodarstw Rolnych, hoteli robotniczych wiele osób utraciło miejsce pracy i poczucie przynależności do grupy społecznej, zaczęło doświadczać ubóstwa i bezdomności. Bezdomność zrobiła się więc „bardziej widoczna”.

Trudno jest sprecyzować ówczesną skalę zjawiska. Tadeusz Kamiński, powołując się na dane Ministerstwa Pracy, przytacza wynik 60-80 tysięcy [Kamiński 1997: 183]. Dla porównania: w 2017 roku bezdomnych było 33408 osób [MRPiPS 2017: 24]. Trzeba jednak podkreślić, że niektórzy przedstawiciele organizacji pozarządowych podczas dyskusji towarzyszących konferencjom i warsztatom poświęconym problematyce bezdomności i ubóstwa określają liczbę bezdomnych na 40-50 tysięcy. Wiadomo jednak, że ze względu na specyfikę sytuacji osób pozbawionych własnego schronienia (np. mobilność, niechęć do korzystania z pomocy instytucji) ich dokładna liczba nigdy i nigdzie nie zostanie podana.

Obecnie, gdy bezdomność jest zauważalna, a decydenci odpowiedzialni za kształtowanie polityki społecznej sami spostrzegają potrzebę jej badania, nadal istnieją obszary tematyczne, które wymagają zgłębienia. O ile istnieją opracowania na temat definiowania terminu bezdomność, przyczyn jej doświadczania, opisywane są różne formy pracy z osobami bez dachu nad głową, np. streetworking [Dębski, Michalska 2012; Housing First-Wygnańska 2016], o tyle rzadkością są jeszcze prace, które nie tylko „dawałyby głos ubogim” [Tarkowska, Warzywoda-Kruszyńska, Wódz 2003: 8; Kapuściński 2008], ale i prezentowały kwestie ich podmiotów bezdomności, w tym biedy - rozumienia własnej godności, postrzegania sytuacji życiowej, w której się znaleźli.

Artykuł stanowi próbę uzupełnienia zauważalnej luki. W jego kolejnej części zostaną przedstawione zagadnienia odnoszące się do rozumienia pojęcia godność wraz z odniesieniem jej do bezdomności, a także wyniki badań własnych, stanowiących fragment większego projektu zatytułowanego „Poczucie własnej godności wybranych grup klientów korzystających z pomocy społecznej” realizowanego przez autorki od marca 2018 r. 


\section{Godność ludzka - wyjaśnienia terminologiczne}

Godność jest różnie definiowana. Potocznie nazywana dumą czy honorem, utożsamiana jest też z podmiotowością, warunkami życia i szacunkiem ze strony innych. Jest wartością wrodzoną, uniwersalną i nieutracaną, której koncepcje leżą w kręgu zainteresowań teologów, filozofów, prawa, psychologów, socjologów i pedagogów [Mariański 2016: 31]. Godność bywa rozumiana jako przestrzeganie powinności moralnych, tak wobec innych, jak i wobec siebie, nie naruszanie cudzych uprawnień oraz jako godne postępowanie i godne życie [tamże: 41].

Obok godności ludzkiej, utożsamianej z prawami człowieka, wyróżnia się godność osobistą - cechę charakteru. Według Janusza Gajdy jest ona zmienna historycznie, wynika z natury człowieczeństwa i odnosi się do poczucia własnej wartości, ideałów, bronienia swojego stanowiska [Gajda 2003: 80]. Wojciech Chudy wyodrębnia zaś godność osobową, osobistą (nabywaną w toku interakcji z innymi, na przykład w sferze zawodowej, wynikającą z uznania oraz nadanego i odczuwanego statusu) oraz osobowościową (będącą stosunkiem do samego siebie, własną wartością) [Chudy 2004: 78].

Problematyka artykułu skłania do odróżnienia godności jako ogólnej wartości od poczucia własnej godności. Jak zauważa Janusz Mariański, poczucie to stanowi elementarny warunek rozwoju osobowości i utrzymania zdrowia psychicznego [Mariański 2016: 122]. Kształtuje się na skutek działania z innymi, poczucia odpowiedzialności za innych i akceptacji z ich strony. Powołując się na Zenomenę Płużek, wymienia trzy elementy struktury poczucia godności:

- szacunek do siebie samego - posiadanie i przestrzeganie wewnętrznego systemu wartości,

- zaufanie do siebie - co pozwala na podejmowanie decyzji, wykonywani trudnych zadań,

- wysoki poziom samoakceptacji - obejmujący znajomość siebie, w tym swoich mocnych i słabszych stron.

Biorąc je wszystkie pod uwagę można wyłonić różne poziomy poczucia własnej godności. Im wyższe będą wyznawane wartości, większa świadomość dokonywanych wyborów i większy wysiłek, by przyswojone wartości interioryzować, tym poczucie to będzie wyższe [Mariański 2016: 122, za Płużek 1989: 298]. Dla autorek artykułu zastanawiające było, jaki poziom prezentują osoby znajdujące się w trudnej, czasem wręcz tragicznej, sytuacji życiowej (tj. doświadczające bezdomności) oraz jak, w świetle dotychczas opublikowanej literatury, przedstawiana jest ich godność? Próbę odpowiedzi na te pytania przedstawiono poniżej. 


\section{Godność osób bezdomnych}

Wydane dotychczas publikacje na temat bezdomności pomijają kwestie godności bezdomnego. Jeśli taka problematyka jest podejmowana, najczęściej nawiązuje do społecznego odbioru, wizerunku bezdomnego, który jest pejoratywny. Bezdomny śpi na ulicy, jest brudny, zajmuje miejsce w komunikacji miejskiej nie płacąc za bilet, budzi odrazę i strach. Bezdomnym „przypina się łaty": pijaka (ale nie osoby chorej - uzależnionej od alkoholu), darmozjada, złodzieja.

Z pilotażowego badania na Mazowszu, wykonanego przez Martę Mikołajczyk na przełomie 2014 i 2015 r. wynika, że negatywne cechy niemającym własnego domu przypisują także praktycy - kadra ośrodków: noclegowni, schronisk, domów dla samotnych matek, ośrodków interwencji kryzysowej (metodologia i wybrane wyniki badania) [por.: Mikołajczyk 2018: 20-21; Mikołajczyk 2015]. Trzydzieści osób: pracowników socjalnych, wychowawców/opiekunów, psychologów/psychoterapeutów oraz przedstawicieli kadry zarządzającej (kierownicy, dyrektorzy) poproszono, by spośród 14 określeń (siedem pozytywnych i siedem negatywnych) wybrali sześć, które ich zdaniem najlepiej charakteryzują ich klienta. W toku analizy zebranego materiału usunięto warianty „nieudacznik" oraz „ma końskie zdrowie", gdyż ani razu nie zostały zaznaczone. Rozkład odpowiedzi ilustruje rysunek 1 .

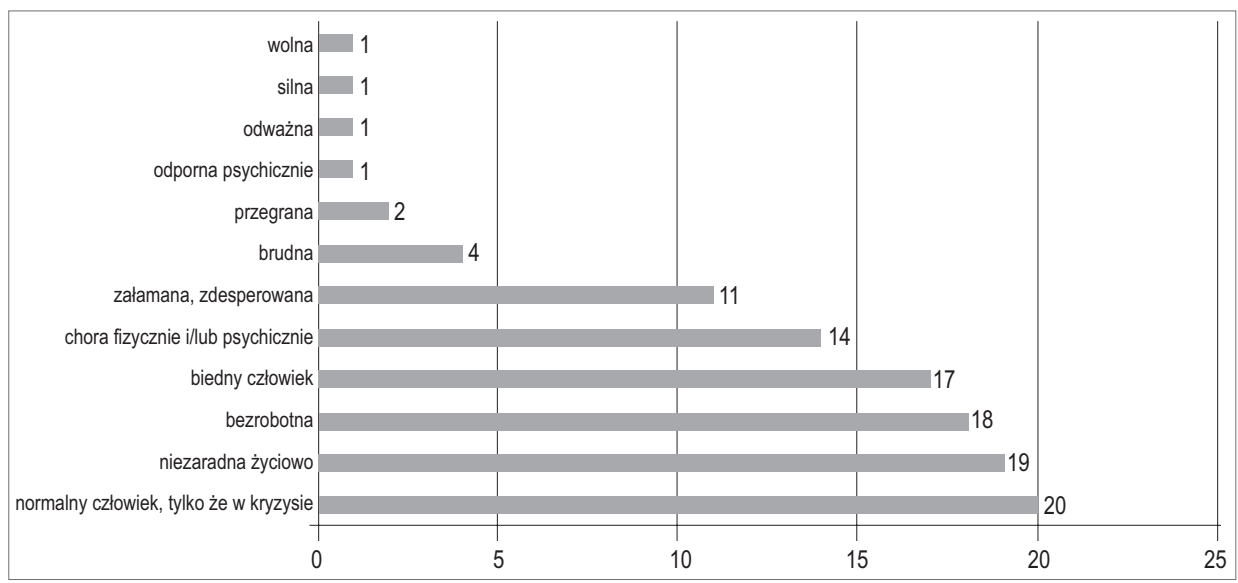

Rysunek 1 . Cechy przypisywane osobom doświadczającym bezdomności w opinii praktyków - pracowników schronisk, noclegowni, ośrodków interwencji kryzysowej, domów samotnych matek

$\mathrm{N}=30$, badani mogli zaznaczyć do 5 odpowiedzi

Źródło: Opracowanie własne 
Najczęściej wymieniane określenie to „normalny człowiek, tylko że w kryzysie" (20 razy). W dalszej kolejności epitetowano bezdomnego jako: niezaradnego życiowo, bezrobotnego, czy biednego człowieka (odpowiednio: 19, 18, 17 ankietowanych). Co druga osoba zwróciła uwagę na jego choroby, a co trzecia na załamanie i zdesperowanie. Według czterech, bezdomny był brudny. Dwie osoby uznały go za przegranego. Ankietowani niemal pominęli cechy pozytywne. Odporność psychiczna, odwaga, siła oraz poczucie wolności zostały wskazane tylko raz.

Co ciekawe, same osoby bezdomne prezentują negatywny obraz samych siebie. Z badań zrealizowanych przez Aleksandrę Nowakowską wynika, że niemający dachu nad głową oceniają siebie gorzej, niż istniejący autostereotyp bezdomnych. Ponadto, wśród całej zbiorowości pozbawionych własnego schronienia kobiety były wobec siebie bardziej krytyczne, niż mężczyźni i nie akceptowały siebie jako bezdomnej, przypisując sobie - częściej niż mężczyźni - cechy: niedokładna, niechlujna, nieopiekuńcza, niewytrwała (co według Nowakowskiej może być spowodowane generalną tendencją kobiet do niższej samooceny). One także częściej wskazywały na negatywne cechy wszystkich bezdomnych przypisując im bycie: niesystematycznymi, nietolerancyjnymi, nieopiekuńczymi, nietroskliwymi, karzącymi, niechlujnymi i nieatrakcyjnymi. A. Nowakowska zwraca też uwagę, że najbardziej negatywny obraz samych siebie miały osoby o krótkim i o długim stażu bezdomności (faza wstępna, chroniczna i długotrwała; por. Jaździkowski 2001/2002: 64-67). Pierwsze - bo prawdopodobnie nie postrzegają siebie jako bezdomne i nie akceptują własnej sytuacji, drugie - bo ich poczucie bierności i beznadziei narasta [Nowakowska 2008: 338-345].

Kwestie postrzegania bezdomnego - jego cech, podejmowanych działań i umiejętności - były tematem badań wykonanych pod kierunkiem Moniki Oliwy-Ciesielskiej w Poznaniu. Dwie grupy: bezdomnych i przechodniów ulicznych przemieszczających się wokół dworców i głównych ulic miasta (czyli w miejscach, w których bezdomność jest widoczna) proszono o dokończenie zdań, między innymi: Bezdomny wygląda jak... Bezdomny zachowuje się jak... Bezdomny jest... Uzyskane odpowiedzi poddano analizie jakościowej i utworzone $w$ ten sposób kategorie -ilościowej. Z zebranego w ten sposób materiału (pochodzącego od 190 bezdomnych i 193 przechodniów) wynika, że w opisie bezdomnego najczęściej opisywano ich zaniedbany wygląd. Pojawiały się określenia: brudas, lump, pener, łachmaniarz, śmieć. Należy zauważyć, że wiele określeń pokrywało się, to znaczy wskazywały na nie obie grupy. M. Oliwa-Ciesielska zwraca więc uwagę, że bezdomni dobrze odczytują sposób, w jaki są traktowani przez otoczenie. Ich zachowanie najczęściej - przez „domnych” i bezdomnych - epitetowano: człowiek z marginesu, zwierzę, pijak/alkoholik, żebrak, złodziej. Bezdomny najlepiej potrafi: kraść, pić alkohol, żebrać, oszukiwać czy nic nie robić. Jest marginesem społecznym, wyrzutkiem, nikim, nierobem [Oliwa-Ciesielska 2004: 170-175]. 
M. Oliwa-Ciesielska dotknęła także problematyki godności bezdomnych. Przeprowadzone przez nią analizy pokazują, że godność człowieka w ogóle, jak i godność ich samych sprowadzają do własnych zachowań i decyzji. Utożsamiają ją z: szacunkiem do samego siebie, byciem dobrym dla innych, respektowaniem dekalogu, honorem osobistym, samowystarczalnością i utrzymywaniem trzeźwości. Za godne życie uznają życie uczciwe, zgodne z dekalogiem, w dobrobycie materialnym, z zapewnieniem minimum egzystencji, życie, $w$ którym jest się sobą, w którym można komuś pomagać, nie jest się poniżanym i gdy nie trzeba prosić innych o pomoc. Poczucia utraty godności doświadczają na skutek: niewłaściwego zachowania członków rodziny (w tym znęcanie się), nieludzkiego traktowania przez urzędników, osoby świadczące pomoc, poniżania przez przypadkowe osoby, obojętności bliskich [Oliwa-Ciesielska 2004: 152-153].

Negatywne postrzeganie bezdomnych, reprezentowane zarówno przez nich samych, jak i przez otoczenie społeczne prowokuje pytania o poszanowanie godności tych, którzy z różnych powodów pozbawieni są własnego domu. Czy za godne można uznać nazywanie kogoś śmieciem, zwierzęciem, człowiekiem (sic!) $\mathrm{z}$ marginesu, wyrzutkiem?

Bezdomni budzą odrazę. Patrick Declerk opisując swoją praktykę z paryskimi bezdomnymi (których nazywa kloszardami „bo jakoś trzeba ich nazwać", a to "etykieta ani lepsza, ani gorsza od innych") [Declerck 2004: 10] przytacza przypadki reakcji personelu szpitala podczas interwencji wobec bezdomnego: zdarzało się, że pielęgniarki wybiegały z sali, nie mogąc znieść zapachu pacjenta. Jak pisze Declerck „przez większoóć czasu ich nienawidzę. Śmierdzą. Cuchną niespłukiwanym potem, brudnymi nogami, tytoniem, tanim winem" [Declerck 2004: 11]. Trzeba się jednak zastanowić nad przyczynami skrajnego zaniedbania higieny. Czy dostęp do łaźń i punktów wydawania odzieży odpowiada potrzebom poszczególnych gmin i przebywających w ich obrębie bezdomnych? Jakie są zasady korzystania z nich? Ustawa o pomocy społecznej zapewnia m.in. odzież i obuwie odpowiednie do pory roku i rozmiaru bezdomnego [Ustawa z 12 marca $2004 \mathrm{r}$. o pomocy społecznej, art. 17.1], W praktyce jednak jakość ubrań, a czasem nawet ich czystość, nie są optymalne. Bezdomny nie decyduje o tym, co i kiedy zje, ani w co się ubierze. Decyzje te podejmuje kadra instytucji pomocowych, wybierając menu jadłodajni i kompletując paczki z odzieżą.

Brak szacunku dla bezdomnego, a w szerszym znaczeniu brak poszanowania jego godności, wynikają m.in. z tego, jak bezdomny jest postrzegany. Samo postrzeganie - z tego, jak wygląda. Godność bezdomnego, w tym jego poczucie godności, jest więc zagadnieniem, które musi być wzięte pod uwagę przy planowaniu i wdrażaniu programów wychodzenia z bezdomności, redukcji szkód i działań osłonowych. 


\section{Badania własne}

Badania zostały przeprowadzone wśród 57 osób bezdomnych, w tym 20 bezdomnych "ulicznych" oraz 37 osób bezdomnych zamieszkujących Schronisko dla bezdomnych. Wiek badanych osób zawiera się w przedziale 21-6 lat, średnia wieku badanych osób wynosi 41 lat. Uwzględniając płeć badanych osób to przebadano 27 kobiet oraz 30 bezdomnych mężczyzn. Uwzględniając stan cywilny badanych osób to 29 z nich jest panną/kawalerem, 19 osób jest po rozwodzie, natomiast 9 osób pozostaje w związku małżeńskim. Siedem osób bezdomnych nie posiada dzieci, jedno dziecko ma 26 badanych osób, 2-3 dzieci - 17 osób, a czworo dzieci lub więcej ma 7 osób biorących udział w badaniach. Jeżeli chodzi o wykształcenie to wśród badanych bezdomnych 19 osób legitymuje się wykształceniem podstawowym, 21 osób ma wykształcenie zawodowe, 15 osób wykształcenie średnie, natomiast 2 osoby bezdomne wykształcenie wyższe. Ostatnią zmienną socjodemograficzną uwzględnioną w badaniach był staż w bezdomności. I tak, do roku doświadcza bezdomności 17 osób, 1-3 lat - 10 osób, 3-5 lat - 6 osób, zaś powyżej 5 lat doświadcza bezdomności 24 osoby biorące udział w badaniach. Najkrótszy staż doświadczania bezdomności to 3 miesiące, natomiast najdłuższy to 24 lata.

Materiał empiryczny zebrano przy zastosowaniu metody sondażu diagnostycznego, stosując technikę ankiety, jako narzędzie badawcze posłużył Kwestionariusz Poczucia Własnej Godności (KPWG-3) autorstwa S. Steuden i P. Brudka. Narzędzie składa się z 36 stwierdzeń, tworzących 4 wymiary: Poznawczy, Relacyjny Utraty i Doświadczania, a zadaniem badanej osoby jest dokonanie oceny na 5-stopniowej skali, na ile zgadza się z każdym z nich. Wymiar poznawczy określa, w jakim stopniu jednostka traktuje poczucie własnej godności jako sposób postrzegania siebie i własnego funkcjonowania. Wymiar utraty odzwierciedla, na ile utrata poczucia własnej godności wpływa na funkcjonowanie w sferze emocjonalnej i stosunku do siebie. Wymiar relacyjny ujawnia, w jakim stopniu osoba doświadcza poczucia własnej godności poprzez tworzenie i utrzymywanie więzi z innymi. Wymiar doświadczania określa, w jakim stopniu osoba podejmuje refleksję nad własnym poczuciem własnej godności w sytuacjach trudnych lub konfliktowych, w których istnieje ryzyko naruszenia poczucia własnej godności oraz w momentach i decyzjach życiowo ważnych [Steuden 2011].

Wskaźniki rzetelności ( $\alpha$-Cronbacha) dla poszczególnych skal wahają się od .87 do .91 [Brudek, Steuden 2017: 85]. Analizę statystyczną przeprowadzono przy zastosowaniu programu SPSS Statistics 24.0.

Pierwszym krokiem analiz było określenie średnich wartości dla poszczególnych wymiarów poczucia godności osobistej w badanej grupie bezdomnych - statystyki opisowe. Szczegółowe dane zaprezentowano w tabeli 1. 
Tabela 1. Poczucie godności osobistej osób bezdomnych - statystyki opisowe

\begin{tabular}{|l|c|c|c|c|}
\hline $\begin{array}{c}\text { Wymiary poczucia } \\
\text { własnej godności }\end{array}$ & $\begin{array}{c}\text { Wynik } \\
\text { minimalny }\end{array}$ & $\begin{array}{c}\text { Wynik } \\
\text { maksymalny }\end{array}$ & $\begin{array}{c}\text { Wynik średni } \\
(\mathrm{M})\end{array}$ & $\mathrm{Sd}$ \\
\hline Wymiar poznawczy & 12,00 & 53,00 & 20,58 & 7,80 \\
\hline Wymiar utraty & 9,00 & 45,00 & 31,26 & 9,66 \\
\hline Wymiar relacyjny & 7,00 & 35,00 & 13,03 & 6,29 \\
\hline Wymiar doświadczania & 8,00 & 40,00 & 20,25 & 7,17 \\
\hline Wynik ogólny & 48,00 & 180,00 & 130,95 & 22,92 \\
\hline
\end{tabular}

Źródło: Opracowanie własne.

Z danych zawartych w tabeli 1 wynika, że w zakresie wymiaru poznawczego minimalny wynik wynosi 12 pkt, zaś najwyższy 53 pkt. Średni wynik w grupie badanych bezdomnych dla wymiaru poznawczego wynosi $M=20,58$ pkt. Uwzględniając wymiar utraty poczucia godności osobistej bezdomnych to minimalny wynik wynosi 9 pkt, a maksymalny 45, natomiast średnia dla tego wymiaru jest równa $\mathrm{M}=31,26 \mathrm{pkt}$. Analizując wymiar relacyjny poczucia godności osobistej odnotowano, że minimalny wynik wynosi 7 pkt, zaś maksymalny 35 pkt, średnia dla tego wymiaru w badanej grupie to $M=13,03$ pkt. W zakresie wymiaru doświadczania poczucia godności osobistej stwierdzono, że minimalny wynik wynosi 8 pkt a maksymalny to 40 pkt, średnia dla tego wymiaru to $M=20,25$ pkt. Średni ogólny wynik poczucia godności osobistej w badanej grupie bezdomnych wynosi $\mathrm{M}=130,95$ pkt.

Kolejnym krokiem było ustalenie, czy zmienne socjodemograficzne takie, jak płeć, miejsce pobytu (bezdomni „uliczni” vs bezdomni „schroniskowi”) oraz czas doświadczania bezdomności różnicują nasilenie poczucia godności osobistej wśród badanych bezdomnych. W tym celu posłużono się testem t-Studenta dla prób niezależnych oraz MANOVA i testem Tukey'a przyjmując poziom istotności $\mathrm{p}<0,05$. Szczegółowe dane zaprezentowano w tabelach 2-4.

Tabela 2. Poczucie godności osobistej a płeć badanych bezdomnych

\begin{tabular}{|l|c|c|c|c|}
\hline \multicolumn{1}{|c|}{$\begin{array}{c}\text { Wymiary poczucia } \\
\text { własnej godności }\end{array}$} & $\begin{array}{c}\mathrm{K}- \\
\text { kobiety }\end{array}$ & $\begin{array}{c}\text { M- } \\
\text { mężczyźni }\end{array}$ & $\begin{array}{c}\text { Test } \\
\text { t-Studenta }\end{array}$ & $\begin{array}{c}\text { Poziom } \\
\text { istotności } \mathrm{p}\end{array}$ \\
\hline Wymiar poznawczy & 23,22 & 18,20 & 2,473 & $0,021^{*}$ \\
\hline Wymiar utraty & 34,11 & 28,70 & 2,181 & $0,031^{*}$ \\
\hline Wymiar relacyjny & 15,78 & 10,57 & 3,407 & $0,002^{* *}$ \\
\hline Wymiar doświadczania & 20,41 & 18,30 & 2,238 & $0,029^{*}$ \\
\hline Wynik ogólny & 120,63 & 140,23 & $-3,541$ & $0,001^{* * *}$ \\
\hline
\end{tabular}

${ }^{*} \mathrm{p}<0,05 ;{ }^{* *} \mathrm{p}<0,01 ;{ }^{* *} \mathrm{p}<0,001$

Źródło: Opracowanie własne. 
Dane przedstawione w tabeli 2 pokazują, że we wszystkich czterech wymiarach oraz wyniku ogólnym poczucia godności osobistej występują różnice istotne statystycznie pomiędzy badanymi bezdomnymi kobietami a mężczyznami doświadczającymi bezdomności. W zakresie wymiaru poznawczego poczucia godności osobistej badane kobiety osiągnęły wyższy średni wynik $(M=23,22)$, aniżeli badani mężczyźni $(M=18,20)$ a różnica jest istotna statystycznie na poziomie $\mathrm{p}<0,05$. Oznacza to, że badane bezdomne kobiety przypisują większe znaczenie poczuciu godności niż mężczyźni, w odniesieniu do postrzegania siebie i własnego funkcjonowania. Analizując wymiar utraty odnotowano, że badane kobiety uzyskały wyższy średni wynik aniżeli bezdomni mężczyźni ( $\mathrm{p}<0,031)$. Wskazuje to, że doświadczając bezdomności kobiety mają większe poczucie utraty godności osobistej, a co za tym idzie może to mieć odzwierciedlenie w ich funkcjonowaniu emocjonalnym oraz postrzeganiu siebie (wpływ na samoocenę i poczucie własnej wartości). Uwzględniając wymiar relacyjny bezdomne kobiety uzyskały istotnie wyższy średni wynik w porównaniu do bezdomnych mężczyzn ( $p<0,002)$. Wiąże się to z tym, że mniejsza możliwość nawiązywania i podtrzymywania relacji interpersonalnych będzie skutkowała obniżeniem poczucia godności osobistej $\mathrm{u}$ badanych bezdomnych kobiet i przekładała się na funkcjonowanie psychospołeczne. Jeżeli chodzi o wymiar doświadczania to również badane kobiety osiągnęły wyższy średni wynik $(M=20,41)$ niż badani mężczyźni $(M=18,30)$, ponadto uwidoczniona różnica jest bliska istotnej statystycznie $(\mathrm{p}<0,001)$. Można zatem przypuszczać, że kobiety częściej zastanawiają się nad wpływem aktualnej sytuacji życiowej na ich poczucie godności osobistej, w szczególności w sytuacji, gdy opuszczają domy rodzinne i zamieszkują w ośrodkach dla bezdomnych kobiet lub na ulicy. Również w zakresie wyniku ogólne odnotowane różnicę istotną statystycznie pomiędzy bezdomnymi kobietami i mężczyznami, przy czym to właśnie bezdomne kobiety mają niższe poczucie godności osobistej $(\mathrm{M}=120,63)$ niż badani bezdomni mężczyźni $(\mathrm{M}=140,23)$.

Tabela 3. Poczucie godności osobistej a miejsce pobytu badanych bezdomnych

\begin{tabular}{|l|c|c|c|c|}
\hline \multicolumn{1}{|c|}{$\begin{array}{c}\text { Wymiary poczucia } \\
\text { własnej godności }\end{array}$} & $\begin{array}{c}\mathrm{M}- \\
\text { „schronisko" }\end{array}$ & $\begin{array}{c}\mathrm{M}- \\
\text { „uliczni” }\end{array}$ & $\begin{array}{c}\text { Test } \\
\text { t-Studenta }\end{array}$ & $\begin{array}{c}\text { Poziom } \\
\text { istotności p }\end{array}$ \\
\hline Wymiar poznawczy & 22,08 & 17,80 & 2,171 & $0,035^{*}$ \\
\hline Wymiar utraty & 32,40 & 29,00 & 1,308 & 0,249 \\
\hline Wymiar relacyjny & 13,87 & 11,50 & 1,467 & 0,149 \\
\hline Wymiar doświadczania & 21,60 & 17,75 & 1,983 & $0,063 \sim$ \\
\hline Wynik ogólny & 126,08 & 139,95 & $-2,259$ & $0,038^{*}$ \\
\hline
\end{tabular}

${ }^{*} \mathrm{p}<0,05 ; \sim$ poziom zbliżony do istotnego

Źródło: Opracowanie własne. 


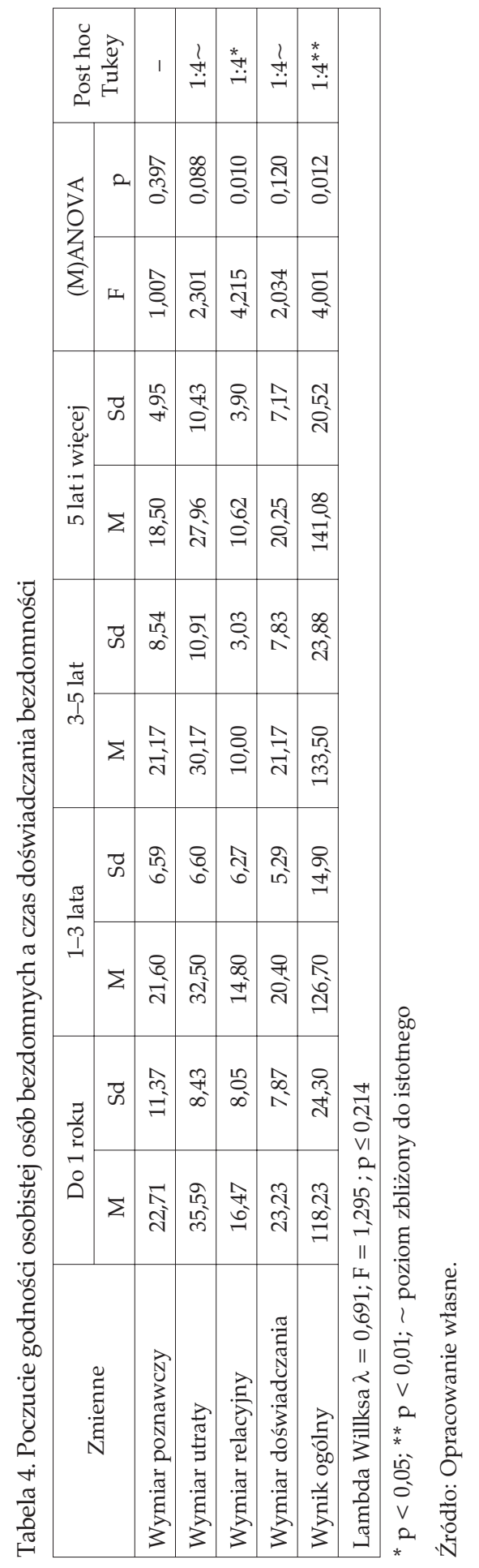


Dane przedstawione $\mathrm{w}$ tabeli 3 pokazują, że istotną statystycznie różnicę odnotowano w zakresie wymiaru poznawczego u badanych osób bezdomnych $(\mathrm{p}<0,035)$. Przy czym bezdomni mieszkający w schroniskach osiągnęli wyższy średni wynik ( $M=22,08)$ niż bezdomni „uliczni” ( $M=17,80)$, co może oznaczać, że osoby bezdomne ze schronisk przypisują większe znaczenie godności osobistej, a także pozytywnej oceniają siebie oraz swoje życie i funkcjonowanie w środowisku społecznym. W ogólnym wyniku poczucia godności osobistej również odnotowano różnicę istotną statystycznie, przy czym bezdomni „uliczni” osiągnęli wyższy średni wynik ( $M=139,95)$, w porównaniu z osobami bezdomnymi mieszkającymi w schroniskach $(\mathrm{M}=126,08)$, to może wskazywać, że miejsce pobytu determinuje poczucie godności osobistej a mieszkanie „na ulicy” prawdopodobnie pozwala tym osobom czuć się „wolnymi”, tzn. nieograniczonymi żadnymi regulaminami, czy nakazami i zakazami ze strony pracowników ośrodków dla osób bezdomnych. Jeżeli chodzi o wymiar doświadczania to uwidoczniła się tendencja bliska istotności statystycznej $(\mathrm{p}<0,063)$, która może wskazywać, że bezdomni „schroniskowi" częściej zastanawiają się nad swoim życiem, trudnościami, z którymi muszą się mierzyć każdego dnia i dostrzegają ryzyko naruszenia godności osobistej w sytuacjach dnia codziennego, jak i w chwilach podejmowania ważnych życiowo decyzji. W pozostałych wymiarach kwestionariusza nie odnotowano różnic istotnych statystycznie.

Uzyskane wyniki przedstawione w tabeli 4 uwidoczniły istnienie różnicy istotnej statystycznie w zakresie Wymiaru relacyjnego poczucia godności osobistej $(\mathrm{p}<0,05)$ oraz w Wyniku ogólnym $(\mathrm{p}<0,01)$. Brak istotnych statystycznie różnic odnotowano w Wymiarze poznawczym poczucia godności osobistej osób bezdomnych mierzonych KPWG-3. Natomiast w Wymiarach: utraty i doświadczania zaobserwowano tendencję zbliżoną do poziomu istotności. Zastosowanie testu post hoc Tukey'a pozwala stwierdzić, że istotne różnice występują pomiędzy osobami bezdomnymi do roku a tymi, którzy doświadczają bezdomności 5 lat i więcej, i to zarówno w Wymiarze relacyjnym, jak i w Wyniku ogólnym. Takie wyniki oznaczają, że dla osób doświadczających bezdomności do roku większe znaczenie ma tworzenie i pielęgnowanie więzi z innymi ludźmi dla podtrzymania godności osobistej, wraz ze stażem pozostawania osobą bezdomną ten aspekt ma mniejsze znaczenie.

\section{Zakończenie}

Celem prezentowanych badań było określenie poczucia godności osobistej wśród osób bezdomnych, ze szczególnym uwzględnieniem takich zmiennych socjodemograficznych, jak: płeć, miejsce pobytu, a także czas doświadczania bez- 
domności. Otrzymane wyniki ujawniły, że badane bezdomne kobiety cechuje niższe poczucie godności osobistej $\mathrm{w}$ porównaniu do bezdomnych mężczyzn biorących udział w badaniach $(\mathrm{p}<0,001)$. Ponadto uwzględniając miejsce pobytu bezdomnych, tzn. „uliczni” vs „schroniskowi” okazało się, że bezdomni „uliczni” odczuwają wyższe poczucie godności osobistej aniżeli bezdomni na co dzień mieszkający w schroniskach i innych placówkach świadczących całodobową pomoc i wsparcie dla tej grupy osób ( $\mathrm{p}<0,05)$. Również czas pozostawania w bezdomności wykazał istotną różnicę pomiędzy osobami bezdomnymi $\mathrm{z}$ najkrótszym i najdłuższym stażem ( $\mathrm{p}<0,01)$. Otrzymanych wyników badań nie można uogólniać na całą populację osól bezdomnych w Polsce, mogą być jednak podstawą do prowadzenia badań na większej populacji bezdomnych. Z poznawczego punktu widzenia istotne jest, aby wskazać czynników, które determinują poczucie godności osobistej (obok zmiennych socjodemograficznych, należałoby uwzględnić zasoby osobiste, takie jak samoocena, poczucie samoskuteczności, system wartości czy poczucie odpowiedzialności, oraz zmienne społeczne związane z systemem pomocy i wsparcia). Zasadnym byłoby także sprawdzenie, na ile osoby, które na co dzień pracują z bezdomnymi a także inni ludzie spotykający bezdomnych mają do nich stosunek, jak ich postrzegają, czy można tutaj mówić o dystansie społecznym do tej grupy osób marginalizowanych i wykluczanych społecznie. Jest to szczególnie ważne w kontekście procesów readaptacji, reintegracji czy inkluzji społecznej.

Podjęta w niniejszym artykule problematyka badawcza jest bardzo rzadko podejmowana i dlatego wydaje się być interesująca zarówno z poznawczego, jak i implikacyjnego punktu widzenia. Każdy człowiek zasługuje na bycie traktowanym z godnością bez względu na swoją sytuację życiową, wygląd, miejsce zamieszkania czy stan posiadania. Godność jest tą cechą, która przysługuje każdemu z nas bez względu na okoliczności, nikt nie może nas jej pozbawić $\mathrm{w}$ rozumieniu obiektywnym, ponieważ wynika ona z faktu urodzenia się człowiekiem. Jednak $\mathrm{w}$ wymiarze subiektywnym, który był przedmiotem badań można człowieka takie poczucia godności pozbawić.

Pracując z osobami bezdomnymi powinno się zwracać dużą uwagę na ich poczucie godności osobistej i podejmować takie działania, które to poczucie godności będą nierzadko przywracały i podnosiły. Należy stworzyć takie warunki, w których bezdomny będzie mógł poczuć się wartościowym człowiekiem, mającym wpływ na podejmowane przez siebie decyzje i otaczającą go rzeczywistość.

\section{Bibliografia}

Brudek P., Steuden S. (2017), Predyktory poczucia własnej godności. Badani osób w okresie późnej dorostości, „Psychoterapia”, nr 4(183), s. 81-92. 
Chudy W., (2004), Godność człowieka wartościq ontyczno-wychowawcza [w:] Ja - Człowiek. Wzrastanie w Godności, Miłości i Miłosierdziu, M. Kalinowski (red.), Wydawnictwo KUL, Fundacja Pomocy Osobom Niepełnosprawnym, Kraków-Lublin.

Declerck P. (2004), Rozbitkowie. Rzecz o paryskich kloszardach, Warszawskie Wydawnictwo Literackie Muza S.A., Warszawa.

Dębski M., Michalska A. (red.) (2012), Podręcznik streetworkera bezdomności, Pomorskie Forum na rzecz Wychodzenia z Bezdomności, Gdańsk.

Gajda J. (2003), Godność [w:] Encyklopedia pedagogiczna XXI wieku, t2, T. Pilch (red.), Wydawnictwo Akademickie Żak, Warszawa.

Jaździkowski M. (2001/2002), Syndrom bezdomności alkoholików pozbawionych domu rodzinnego [w:] W kręgu problematyki bezdomności polskiej, A. Duracz-Walczak (red.),Wydawnictwo Stowarzyszenie Pomocy Bezdomnym; Fundacja Regionalne Centrum Informacji i Wspomagania Organizacji Pozarządowych w Gdańsku, Pomorskie Forum na rzecz Wychodzenia z Bezdomności, Towarzystwo Pomocy im. św. Brata Alberta Koło Gdańsk, Warszawa-Gdańsk.

Kamiński T. (1997), Bezdomność - wyzwanie dla Kościoła i państwa, „Saeculum Christianum: pismo historyczno-społeczne", nr 4(2), s. 183-193.

Kapuściński R. (2008), Dałem głos ubogim, Wydawnictwo Znak, Kraków.

Mariański J. (2016), Godność ludzka jako wartość społeczno-moralna: mit czy rzeczywistość? Studium interdyscyplinarne, Wydawnictwo Adam Marszałek, Torun.

Mikołajczyk M. (2015), Indywidualne programy wychodzenia z bezdomności - korzyści i ograniczenia, „Niepełnosprawność. Dyskursy pedagogiki specjalnej”, nr 19; Wydawnictwo Uniwersytetu Gdańskiego, Gdańsk, s. 127-140.

Mikołajczyk M. (2018), Rodziny bezdomnych matek. Charakterystyka i działania pomocowe, Wydawnictwo Akademii Pedagogiki Specjalnej, Warszawa.

Ministerstwo Rodziny, Pracy i Polityki Społecznej, Departament Pomocy i Integracji Społecznej (2017), Sprawozdanie z realizacji działan na rzecz ludzi bezdomnych w województwach w roku 2016 oraz Wyniki Ogólnopolskiego badania liczby osób bezdomnych (8/9 luty 2017), Materiał informacyjny, Warszawa.

Nowakowska A. (2008), Obraz samych siebie osób bezdomnych - zjawisko autostereotypu [w:] M. Dębski, S. Retowski, Psychospołeczny profil osób bezdomnych w Trójmieście, Pomorskie Forum na rzecz Wychodzenia z Bezdomności, Gdańsk, s. 334-352.

Plużek Z. (1989), Refleksje nad godnością człowieka [w:] Stuchaj, módl się, pracuj, K. Janicki (red.), Księgarnia św. Wojciecha, Poznań.

Tarkowska E. (2000), Zrozumieć biednego. O dawnej i obecnej biedzie w Polsce, IFIZ PAN, Typografika, Warszawa.

Tarkowska E., Warzywoda-Kruszyńska W., Wódz K. (red.) (2003), Biedni o sobie i swoim życiu, „Śląsk" Wydawnictwo Naukowe, Katowice.

Steuden S. (2011), Psychologia starzenia się i starości, Wydawnictwo Naukowe PWN, Warszawa.

Ustawa z dnia 12 marca 2004 r. o pomocy społecznej (Dz. U. z 2018 r., poz. 650, 700).

Wygnańska J. (red.) (2016), "Najpierw mieszkanie” - dlaczego tak?, Fundacja Ius Medicinae, Warszawa. 